\title{
Does Financial Remoteness Affect Foreign Direct Investment?
}

\author{
MICHAEL MACHOKOTO* \\ The Faculty of Business and Law, The University of Northampton, UK
}

\author{
LANRE KASSIM \\ The World Bank, Chad Office, Chad
}

\begin{abstract}
We examine the effect of financial remoteness on foreign direct investment (FDI) using a sample of 173 countries over the period 1970-2015. Our results show that financial remoteness has a significant negative effect on FDI, which suggests that proximity to major financial centres is a key factor in deciding on foreign investments. Our results are robust to alternative measures of financial remoteness and controlling for other determinants of FDI from the literature.
\end{abstract}

Keywords: Foreign direct investment, Empirical, Financial remoteness, Proximity.

JEL classification: F21, N20, O50, C33

\section{Introduction}

Recent literature suggests that the role of distance in determining different levels of financial activities cannot be overemphasised. For instance, Malloy (2005) shows that geographically proximate analysts perform better than other analysts because the former possess information advantage over the latter. In addition, Coval and Moskowitz (2001) find that fund managers earn substantial abnormal returns (an additional return of 2.67 per cent per year) on

\footnotetext{
* The views expressed in this paper are those of the author and do not necessarily represent the views of the World Bank, its executive board or the World Bank Management. The authors wish to thank the editor, Jerzy (Jurek) Konieczny, and three anonymous reviewers for their helpful comments that have improved the paper. We also thank Nadeem Aftab, Ouarda Dsouli, Alois Nyanhete and Eghosa Igudia for useful comments and suggestions on previous versions of this paper. We benefited from the comments of seminar participants at the University of Northampton and Heriot-Watt University. The usual disclaimer appliesMachokoto: The Faculty of Business and Law, The University of Northampton, Park Campus, Boughton Green Road, Northampton, NN2 7AL, UK, Email: michael.machokoto@northampton.ac.uk; Kasim: The World Bank, Chad Office, BP146, N'Djamera, Chad, Email: okassim@worldbank.org.
}

(C) 2019 Michael Machokoto and Lanre Kassim. Licensed under the Creative Commons Attribution Noncommercial 3.0 Licence (http://creativecommons.org/licenses/by-nc/3.0/. Available at http: //rofea.org. 
investments in close proximity while Berger and Woitek (2005) demonstrates that larger banks tend to lend at greater distance and they interact more impersonally with their borrowers. Similarly, Rose and Spiegel (2009) also show that volatility in growth rates of both output and consumption increase with distance from major financial centres. Rose and Spiegel (2009) introduced the concept of international financial remoteness which captures the natural logarithm of the distance to the nearest major financial centres (New York, London or Tokyo). The main advantage of the aforementioned geography-based measure is its potential exogeneity. Subsequently, the variable was adopted by Schmitz (2011) who find that remote countries tend to have a more positive net external position. Despite the importance of proximity to financial centres, there are no empirical studies that directly examine the effect of financial remoteness on foreign direct investment (FDI, henceforth).

We extend the literature by examining the effects of financial remoteness on FDI for a panel of 173 countries over the period 1970-2015. We posit that financial remoteness has a negative effect on FDI for two reasons. First, a model by Rose and Spiegel (2007) predicts that the costs of moving assets to banks located offshore increases with physical distance which tends to reduce both the share of offshore banking and competition in the domestic banking system from offshore financial centres. Similarly, Degryse and Ongena (2005) show that loan rates are increasing in physical distance between the firm and the lending bank which results spatial price discrimination. Second, models of Martin and Rey $(2004,2006)$ show that transactions costs for international assets on exchanges tend to be higher than those for domestic assets. This shows that in theory, proximity to financial centres has a significant effect on lending and transaction costs, which can also extend to foreign direct investment. ${ }^{1}$ The intuition motivating this study is that countries that are proximate to financial centres are more financially integrated which reducing information asymmetry and agency costs, while those further away are less integrated which increases monitoring costs and reduces the observability of those managing the investment projects. Combined, this should result in a negative relationship between FDI and distance from main financial centres.

Consistent with our hypothesis, countries that are in proximity to the major financial centres (London, New York or Tokyo) have higher levels of foreign direct investment relative to those that are more distant. Our results show that financial remoteness has a statistically and economically significant negative effect on FDI, as a one standard deviation increase in financial remoteness results in an $11 \%$ decrease in FDI relative to the sample mean. This result is robust to alternative measures of financial remoteness (see definitions in Appendix A) and controlling for other factors that affect FDI from the literature. Our results provide further evidence on how financial remoteness negatively impacts economic activities.

\footnotetext{
${ }^{1}$ A study by Lin and Png (2003) also find that international investors can reduce these monitoring costs which increase with distance by structuring investments further away from home as joint ventures.
} 


\section{MACHOKOTO, KASIM Financial Remoteness and FDI}

The rest of the paper is organised as follows. Section 2 describes the data and presents some summary statistics. Section 3 introduces the empirical approach. Section 4 discusses the empirical findings and robustness tests. Section 6 concludes.

\section{Data}

Our unbalanced sample consists of 173 countries drawn from the World Bank Database over the period 1970-2015. Prior periods have limited observations to allow for meaningful analysis. We retain only countries with non-missing data on key variables. Consistent with Rose and Spiegel (2009), we also drop the USA, Japan, and the UK as our measure of financial remoteness is based on the distance from these three main financial centres. The following variables were adopted for the purposes of this study:

a) Foreign direct investment ( $f d i)$ is the dependent variable measured as a percentage of GDP. The independent variables follow the extensive literature on FDI such as Chanegriha et al. (2017) which shows openness, democratic governance, geographic and coastal locations as robust determinants of FDI. They include:

b) International Financial Remoteness (ldistmbc): This is our main independent variable of interest as proposed in Rose and Spiegel (2009). It is measured as the natural logarithm of the great-circle distance to closest major financial center (London, New York, or Tokyo). Intuitively, nearness to major financial center reduces monitoring and transaction costs and thus, encourages foreign direct investment. Therefore, we expect a negative sign on ldistmbc.

c) Political instability (polity2): This is a modified version of the POLITY variable, ranging between -10 (total autocracy) and 10 (total democracy). It measures the "intensity" or "degree" of democratization in a country, based on underlying variables such as competitiveness of executive recruitment, openness of executive recruitment, constraint on the chief executive, regulation of participation and competitiveness of political participation. Democratic regimes have a positive effect on FDI inflows and thus, we expect a positive on polity2 (see, Marshall and Jaggers, 2002).

d) Trade openness (trade): This variable captures the impact of multilateral and bilateral trade agreements. In addition, it measures the effect of regional integration. A more open economy attracts FDI inflows and hence, trade is expected to have a positive sign.

e) $\log$ of GDP (loggdp) and GDP growth (growth): These variables measure the overall level of development of an economy. Although related to the trade and financial sector variables, the explanatory powers of loggdp and growth are potentially better as they reflect the administrative capacity and institutional quality of an economy. In addition, they capture the effects of sectoral variables such as agriculture and manufacturing. loggdp 
is expected to be negative because FDI is measured as a percentage of GDP; hence, an increase in the denominator decreases the overall variable. GDP growth is expected to be positive.

f) Credit to GDP ratio (credit): This is measured as the flow of domestic credit to the private sector. It captures the overall development of the banking sector. The relationship between FDI flows and domestic credit is generally ambiguous in the literature; while some studies have shown a significant positive relationship, others have found no significant relationship at all (see, Tsaurai, 2014). Thus, the sign on credit will be determined by the regression model.

g) island is a dummy variable that takes the value of one for countries that are islands and otherwise zero, landlis a dummy variable that takes the value of one for countries that are landlocked and otherwise zero. $2 \mathrm{We}$ include logarithm of latitude (llat) to control for the positive link between distance to the equator and economic development which consequently affects foreign direct investment (see, Dalgaard and Strulik, 2018). ${ }^{3}$.

Table 1 presents the basic statistics (Panel A) and correlations (Panel B) for the variables used. The mean (median) FDI, financial remoteness, polity2, log of GDP, growth, credit and $\log$ of latitude is 3.476 (1.691), 7.735 (7.886), 0.143 (-1 .000), 81.880 (72.020), 23.270 (23.160), 3.833 (3.897), 34.600 (28.530), and 2.846 (2.944), respectively. As Panel A shows, FDI can be negative and this is due three countries (Bermuda, Iraq and Suriname) that are experiencing large divestments. ${ }^{4}$ The pairwise correlations in Panel B show that FDI is positively correlated with trade, growth and credit, while it is negatively correlated with financial remoteness (ldistmbc), political regime (polity2), logarithm of GDP (loggdp), and logarithm of latitude (llat). The negative correlation of -0.077 between FDI and financial remoteness shows an apriori indication that FDI decreases with distance from the main financial centres. The other correlations are as expected and consistent with the literature.

Figure $1 \mathrm{a}$ and $1 \mathrm{~b}$ plots the mean FDI and the scatter plot of FDI and financial remoteness, respectively. Figure 1a shows a general increase in FDI over time, while Figure 1b shows a general decrease in FDI with financial remoteness. This is consistent with the negative correlation in Table 1 and our hypothesis that investors are less willing to invest in remote locations as information asymmetry and monitoring costs increase with distance from the main financial centres (London, New York or Tokyo).

2 These variables are informed by the literature (see, Asiedu et al., 2015; Bevan and Estrin, 2004; Blonigen and Piger, 2014; Farla et al., 2016; Lane and Milesi-Ferretti, 2008).

${ }^{3}$ Indeed, we acknowledge that there are other potential determinants of FDI; however, most of these determinants are highly correlated which may lead to incorrect signs and magnitude of coefficients

${ }^{4}$ Our results are not significantly affected by excluding these countries from our sample. 


\section{MACHOKOTO, KASIM Financial Remoteness and FDI}

Table 1: Basic statistics and correlations

Panel A: Basic statistics

\begin{tabular}{lcrrrrrrr}
\hline Variable & $\mathrm{N}$ & Mean & Stdev & Min & $\mathrm{p} 25$ & Meadian & $\mathrm{p} 75$ & Max \\
\hline fdi & 5655 & 3.476 & 6.499 & -58.980 & 0.479 & 1.691 & 4.298 & 89.480 \\
ldistmbc & 5655 & 7.735 & 0.650 & 5.188 & 7.493 & 7.886 & 8.163 & 8.707 \\
polity2 & 5655 & 0.143 & 6.982 & -10.000 & -7.000 & -1.000 & 8.000 & 10.000 \\
trade & 5655 & 81.880 & 50.240 & 6.320 & 49.600 & 72.020 & 101.900 & 531.700 \\
loggdp & 5655 & 23.270 & 2.276 & 17.280 & 21.660 & 23.160 & 24.930 & 30.030 \\
growth & 5655 & 3.833 & 5.772 & -50.250 & 1.495 & 3.897 & 6.252 & 150.000 \\
credit & 5655 & 38.270 & 34.600 & 0.000 & 13.970 & 28.530 & 52.720 & 312.200 \\
llat & 5655 & 2.846 & 0.950 & 0.000 & 2.485 & 2.944 & 3.555 & 4.174 \\
\hline
\end{tabular}

Panel B: Correlations

\begin{tabular}{lllllllll}
\hline Variable & $f d i$ & ldistmbc & polity2 & trade & loggdp & growth & credit & llat \\
\hline fdi & 1.000 & & & & & & & \\
ldistmbc & $-0.077^{* * *}$ & 1.000 & & & & & & \\
polity2 & $-0.027^{*}$ & $-0.241^{* * *}$ & 1.000 & & & & & \\
trade & $0.439^{* * *}$ & $-0.116^{* * *}$ & 0.007 & 1.000 & & & & \\
loggdp & $-0.042^{* *}$ & $-0.373^{* * *}$ & $0.170^{* * *}$ & $-0.140^{* * *}$ & 1.000 & & & \\
growth & $0.162^{* * *}$ & $0.061^{* * *}$ & $-0.037^{* *}$ & $0.127^{* * *}$ & -0.001 & 1.000 & & \\
credit & $0.154^{* * *}$ & $-0.382^{* * *}$ & $0.260^{* * *}$ & $0.297^{* * *}$ & $0.441^{* * *}$ & $-0.064^{* * *}$ & 1.000 & \\
llat & -0.012 & $-0.495^{* * *}$ & $0.168^{* * *}$ & $-0.098^{* * *}$ & $0.366^{* * *}$ & $-0.054^{* * *}$ & $0.294^{* * *}$ & 1.000 \\
\hline
\end{tabular}

\section{Methodology}

We adopt a panel-data approach to examine the effect of financial remoteness on FDI. The following empirical model is employed:

$$
F D I_{j t}=\alpha_{0}+\alpha_{1} F R_{J}+\beta X_{j t}+\epsilon_{j t}
$$

where $F D I_{j t}$ is foreign direct investment (as a percentage of GDP) for country $j$ at time $t ; \alpha_{0}$ is a constant; $\alpha_{1}$ and $\beta$ are parameters to be estimated; $F R_{J}$ is a measure of financial remoteness; $X_{j t}$ is a vector of control variables (as previously explained); and $\epsilon_{j t}$ is an error term. The vector of control variables includes the political regime (polity2), logarithm of GDP (loggdp), and logarithm of latitude (llat). We estimate all our different specification of Equation (1) with OLS, using standard errors robust to the presence of heteroskedasticity and controlling for time-fixed effects. 
Fig 1: Financial remoteness and foreign direct investment

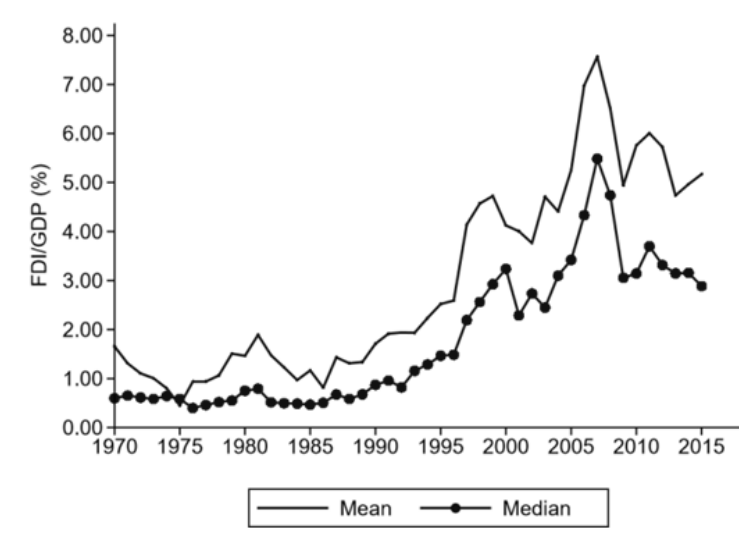

(a) Time variations

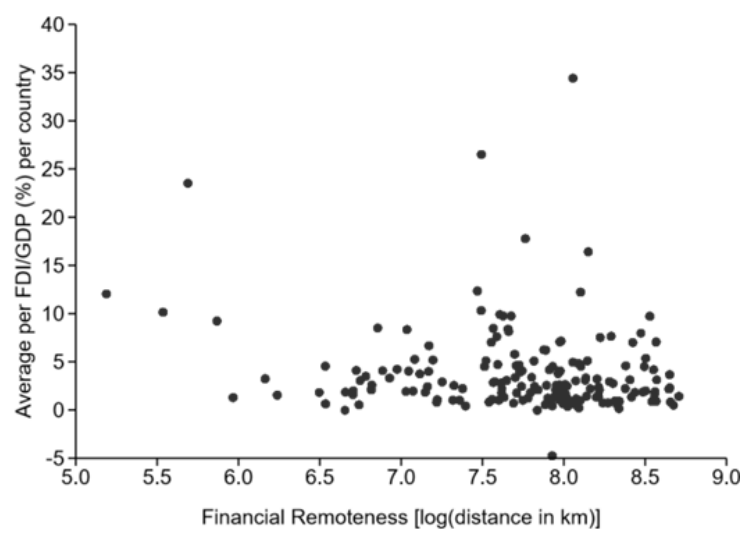

(b) FDI and financial remoteness

The conventional approach to cross-country FDI regressions is to adopt fixed effects or GMM model. However, our main variable of interest (international financial remoteness, ldistmbc) is time invariant which means makes the aforementioned approaches unsuitable. While ldistmbc has the advantage of plausible exogeneity, we do not overstate the overall strength of our results due to potential endogeneity issues. Nevertheless, the addition of time fixed effects addresses cross-section dependency, a source of endogeneity in cross-country regressions of this nature. Overall, we think the useful insights from unearthing a new significant determinant of FDI flows should not be neglected. ${ }^{5}$

\section{Results}

Table 2 presents results for the eight different specifications of Equation (1) relating FDI to financial remoteness and its determinants. In column (1), we examined the "pure" effect of financial remoteness on FDI by including only the variable FR. In columns (2) - (7) we include all the aforementioned variables (in Section 2). We adopt this approach to ascertain the sensitivity of our variables with respect to sign and significance. The results in columns (1) - (2) show that financial remoteness has a significant negative effect on FDI. These results are economically and statistically significant, as a one standard deviation increase in financial remoteness results in a $10 \%$ to $14 \%$ decrease in FDI relative to the sample mean of 7.735 $(2,287 \mathrm{~km})$.

\footnotetext{
${ }^{5}$ Given potential endogeneity concerns, we also estimated the models using lags of the independent variables. These results are similar and are available on request.
} 
MACHOKOTO, KASIM Financial Remoteness and FDI

Table 2: The effects of financial remoteness on FDI

\begin{tabular}{|c|c|c|c|c|c|c|c|}
\hline \multicolumn{8}{|c|}{ Dependent variable: Foreign Direct Investment (FDI) } \\
\hline Variables & (1) & $(2)$ & $(3)$ & (4) & $(5)$ & $(6)$ & $(7)$ \\
\hline ldistmbc & $\begin{array}{r}-0.725^{* * *} \\
(0.190)\end{array}$ & $\begin{array}{r}-0.656^{* * * *} \\
(0.182)\end{array}$ & $\begin{array}{r}-0.593 * * \\
(0.253)\end{array}$ & $\begin{array}{r}-0.712 * * * \\
(0.182)\end{array}$ & $\begin{array}{r}-0.590 * * * \\
(0.190)\end{array}$ & $\begin{array}{r}-0.520^{* * *} \\
(0.186)\end{array}$ & $\begin{array}{r}-0.732 * * \\
(0.309)\end{array}$ \\
\hline polity2 & & $\begin{array}{r}-0.026^{* *} \\
(0.011)\end{array}$ & $\begin{array}{r}-0.020 * \\
(0.011)\end{array}$ & $\begin{array}{r}-0.033 * * * \\
(0.011)\end{array}$ & $\begin{array}{r}-0.027 * * \\
(0.011)\end{array}$ & $\begin{array}{r}-0.036^{* * *} \\
(0.011)\end{array}$ & $\begin{array}{r}-0.007 \\
(0.023)\end{array}$ \\
\hline trade & & $\begin{array}{r}0.045^{* * *} \\
(0.004)\end{array}$ & $\begin{array}{r}0.046^{* * *} \\
(0.004)\end{array}$ & $\begin{array}{r}0.045^{* * *} \\
(0.004)\end{array}$ & $\begin{array}{r}0.046^{* * *} \\
(0.004)\end{array}$ & $\begin{array}{r}0.046^{* * *} \\
(0.007)\end{array}$ & $\begin{array}{r}0.045 * * * \\
(0.005)\end{array}$ \\
\hline $\operatorname{loggdp}$ & & $\begin{array}{r}-0.226^{* * *} \\
(0.053)\end{array}$ & $\begin{array}{r}-0.203 * * * \\
(0.057)\end{array}$ & $\begin{array}{r}-0.189 * * * \\
(0.058)\end{array}$ & $\begin{array}{r}-0.232 * * * \\
(0.052)\end{array}$ & $\begin{array}{r}-0.165^{* *} \\
(0.074)\end{array}$ & $\begin{array}{r}-0.389 * * * \\
(0.093)\end{array}$ \\
\hline growth & & $\begin{array}{r}0.125 * * * \\
(0.047)\end{array}$ & $\begin{array}{r}0.127^{* * * *} \\
(0.048)\end{array}$ & $\begin{array}{r}0.126^{* * * *} \\
(0.047)\end{array}$ & $\begin{array}{r}0.125^{* * *} \\
(0.047)\end{array}$ & $\begin{array}{r}0.131 * * \\
(0.054)\end{array}$ & $\begin{array}{r}0.084 \\
(0.071)\end{array}$ \\
\hline credit & & $\begin{array}{r}0.005 \\
(0.005)\end{array}$ & $\begin{array}{r}0.006 \\
(0.005)\end{array}$ & $\begin{array}{r}0.003 \\
(0.004)\end{array}$ & $\begin{array}{r}0.005 \\
(0.005)\end{array}$ & $\begin{array}{l}-0.001 \\
(0.005)\end{array}$ & $\begin{array}{r}0.007 \\
(0.008)\end{array}$ \\
\hline easiapac & & & $\begin{array}{l}-0.454 * \\
(0.243)\end{array}$ & & & & \\
\hline eurcasia & & & $\begin{array}{r}0.064 \\
(0.258)\end{array}$ & & & & \\
\hline namer & & & $\begin{array}{r}0.309 \\
(0.407)\end{array}$ & & & & \\
\hline sasia & & & $\begin{array}{r}-0.677 * * * \\
(0.236)\end{array}$ & & & & \\
\hline ssafrica & & & $\begin{array}{r}0.331 \\
(0.232)\end{array}$ & & & & \\
\hline island & & & & $\begin{array}{r}0.509 * * \\
(0.253)\end{array}$ & & & \\
\hline landl & & & & $\begin{array}{l}-0.279 \\
(0.251)\end{array}$ & & & \\
\hline llat & & & & & $\begin{array}{r}0.109 \\
(0.085)\end{array}$ & & \\
\hline Constant & $\begin{array}{r}7.184 * * * \\
(1.528)\end{array}$ & $\begin{array}{r}8.476 * * * \\
(1.942)\end{array}$ & $\begin{array}{r}7.375^{* * *} \\
(2.224)\end{array}$ & $\begin{array}{r}8.140 * * * \\
(1.957)\end{array}$ & $\begin{array}{r}7.786 * * * \\
(2.086)\end{array}$ & $\begin{array}{r}6.575^{* *} \\
(2.832)\end{array}$ & $\begin{array}{r}12.260 * * * \\
(3.093)\end{array}$ \\
\hline$N$ & 5,655 & 5,655 & 5,655 & 5,655 & 5,655 & 3,970 & 1,685 \\
\hline$R \wedge 2$ & 0.0913 & 0.251 & 0.252 & 0.251 & 0.251 & 0.226 & 0.276 \\
\hline
\end{tabular}

The other determinants of FDI used as control variables, namely; the political regime (polity2), logarithm of GDP (loggdp), and logarithm of latitude (llat), are generally consistent with theory and prior studies (e.g., Asiedu et al., 2015; Bevan and Estrin, 2004; Blonigen and 
Piger, 2014). Political instability (polity2) and size of the economy (loggdp) have a negative effect on FDI, while openness (trade), growth (growth) and domestic private sector credit (credit) have a positive effect.

\section{Robustness}

We check the robustness of our results in several ways. First, we include regional dummies in column (3) to examine whether our results are not just merely capturing regional differences in FDI. The result shows that financial remoteness has a significant negative effect on FDI even after the inclusion of regional categorical dummies (easiapac - Europe, Asia and the Pacific; eurcasia - Europe and Central Asia; namer - North America; sasia - South Asia and ssafrica - Sub-Saharan Africa). Second, the result in column (4) is also robust to controlling for islands and landlocked countries. Third, in column (5), the result remain similarly significant after controlling for latitude. Finally, in columns (6) and (7) of Table 2, we also examine whether our results are not just capturing differences in the levels of economic development. Our results show that countries with high-income levels of economic development (column (7)) are even more affected by financial remoteness than those with low-income levels (column (6)). ${ }^{6}$ Overall our results show a significant negativity effect of financial remoteness on FDI that is robust to alternative specifications and measures of financial remoteness (see Appendix A).

\section{Conclusions}

We empirically examine the effects of financial remoteness on FDI, while controlling for other determinants of FDI from the literature. Our results show that financial remoteness has a statistically and economically significant negative effect on FDI. This result suggests that proximity to financial centres is an important factor that is also considered by foreign investors beyond the other factors in the FDI literature. Further research could examine the robustness of the relationship between international financial remoteness and FDI using a combination of other explanatory variables and the application of other econometric methodologies.

\section{Disclaimer statement}

The views expressed in this paper are those of the authors and do not necessarily represent the views of the World Bank, its Executive Board, or World Bank Management.

\footnotetext{
6 Appendix A shows that our results are robust to alternative definitions of financial remoteness. The coefficients for the alternative measures of financial remoteness are lower as the closest or average distance to several financial centres is lower than that to the three main centres (London, New York and Tokyo). These alternative measures of remoteness are based on Rose and Spiegel (2009).
} 


\section{MACHOKOTO, KASIM Financial Remoteness and FDI}

\section{References}

Asiedu, Elizabeth, Yi Jin, and Isaac K. Kanyama, 2015, The impact of HIV/AIDS on foreign direct investment: Evidence from Sub-Saharan Africa, Journal of African Trade 2, 1-17.

Berger, Helge, and Ulrich Woitek, 2005, Does Conservatism Matter? A Time-Series Approach to Central Bank Behaviour*, The Economic Journal 115, 745-766.

Bevan, Alan A., and Saul Estrin, 2004, The determinants of foreign direct investment into European transition economies, Journal of Comparative Economics 32, 775-787.

Blonigen, Bruce A., and Jeremy Piger, 2014, Determinants of foreign direct investment, Canadian Journal of Economics/Revue canadienne d'économique 47, 775-812.

Chanegriha, Melisa, Chris Stewart, and Christopher Tsoukis, 2017, Identifying the robust economic, geographical and political determinants of FDI: an Extreme Bounds Analysis, Empirical Economics 52, 759-776.

Coval, Joshua D., and Tobias J. Moskowitz, 2001, The Geography of Investment: Informed Trading and Asset Prices, Journal of Political Economy 109, 811-841.

Dalgaard, Carl-Johan, and Holger Strulik, 2018, Physiological Constraints and Comparative Economic Development, SSRN Scholarly Paper ID 3235602, Social Science Research Network, Rochester, NY.

Degryse, Hans, and Steven Ongena, 2005, Distance, Lending Relationships, and Competition, The Journal of Finance 60, 231-266.

Farla, Kristine, Denis de Crombrugghe, and Bart Verspagen, 2016, Institutions, Foreign Direct Investment, and Domestic Investment: Crowding Out or Crowding In?, World Development 88, 1-9.

Lane, Philip R., and Gian Maria Milesi-Ferretti, 2008, International Investment Patterns, Review of Economics and Statistics 90, 538-549.

Lin, Chu-Chia S., and Ivan Png, 2003, Monitoring costs and the mode of international investment, Journal of Economic Geography 3, 261-274.

Malloy, Christopher J., 2005, The Geography of Equity Analysis, The Journal of Finance 60, 719-755.

Marshall, Monty G., and Keith Jaggers, 2002, Polity IV Project Dataset Users' Manual, Technical report, University of Maryland.

Martin, Philippe, and Hélène Rey, 2004, Financial super-markets: size matters for asset trade, Journal of International Economics 64, 335-361.

Martin, Philippe, and Hélène Rey, 2006, Globalization and Emerging Markets: With or Without Crash?, American Economic Review 96, 1631-1651. 
Review of Economic Analysis 11 (2019) 219-232

Rose, Andrew K., and Mark M. Spiegel, 2007, Offshore Financial Centres: Parasites or Symbionts?*, The Economic Journal 117, 1310-1335.

Rose, Andrew K., and Mark M. Spiegel, 2009, International financial remoteness and macroeconomic volatility, Journal of Development Economics 89, 250-257.

Schmitz, Martin, 2011, Financial remoteness and the net external position, Working Paper Series 1330, European Central Bank.

Tsaurai, Kunofiwa, 2014, Banking Sector Development and Foreign Direct Investment: A Case of Botswana, Risk governance \& control: financial markets \& institutions 4, 44-50.

\section{Appendix A : Alternative measures of financial remoteness}

The table below presents the results estimating Equation (1) that relates FDI to alternative measures of financial remoteness and control variables. Consistent with Rose and Spiegel (2009), the alternative measures of financial remoteness used are:

ofcmingr is the distance to closest offshore financial center (Column (1));

lbig8min is the distance to the closest eight largest gross debtors (Column (2));

lbig10min is the distance to the closest ten largest gross creditors (Column (3));

Imind55 is the distance to the closest ten countries with the largest gross capital outflows

(Column (4));

Imindv55 is the distance to the closest ten countries with largest gross capital inflows

(Column (5));

lbig8wavg is the average distance to the eight largest gross debtors (Column (6));

lwbig10avg is the average distance to the ten largest gross creditors (Column (7));

lavgd55 is the average distance to the ten countries with largest gross capital outflows (Column (8));

lavgdv55 is the average distance to the ten countries with largest gross capital inflows

(Column (9));

wsldistmbc is the weighted distance to major financial centres with host transactions as weights (Column (10)).

The controls are political instability (polity2), trade openness (trade), log of GDP (loggdp), GDP growth (growth) and credit to GDP ratio (credit). 
MACHOKOTO, KASIM Financial Remoteness and FDI

Dependent variable: Foreign Direct Investment (FDI)

\begin{tabular}{|c|c|c|c|c|c|}
\hline $\begin{array}{l}\text { FR Measure } \\
\text { Variables }\end{array}$ & $\begin{array}{l}\text { ofcmingr } \\
\text { (1) }\end{array}$ & $\begin{array}{l}\text { Ibig8min } \\
(2)\end{array}$ & $\begin{array}{l}\text { lbig10min } \\
\text { (3) }\end{array}$ & $\begin{array}{c}\text { Imind55 } \\
\text { (4) }\end{array}$ & $\begin{array}{c}\text { Imindv55 } \\
(5)\end{array}$ \\
\hline $\begin{array}{l}F R \\
R\end{array}$ & $\begin{array}{r}-0.186^{* *} \\
(0.081)\end{array}$ & $\begin{array}{r}-0.282 * * \\
(0.134)\end{array}$ & $\begin{array}{r}-0.273 * * \\
(0.130)\end{array}$ & $\begin{array}{r}-0.381 * * \\
(0.150) \\
\end{array}$ & $\begin{array}{r}-0.279 * * \\
(0.125) \\
\end{array}$ \\
\hline polity2 & $\begin{array}{r}-0.018^{*} \\
(0.011) \\
\end{array}$ & $\begin{array}{r}-0.022 * * \\
(0.011)\end{array}$ & $\begin{array}{r}-0.022 * * \\
(0.011)\end{array}$ & $\begin{array}{r}-0.024 * * \\
(0.011)\end{array}$ & $\begin{array}{r}-0.022 * * \\
(0.011)\end{array}$ \\
\hline trade & $\begin{array}{r}0.046^{* * * *} \\
(0.004) \\
\end{array}$ & $\begin{array}{r}0.046^{* * *} \\
(0.004) \\
\end{array}$ & $\begin{array}{r}0.046^{* * *} \\
(0.004) \\
\end{array}$ & $\begin{array}{r}0.046^{* * *} \\
(0.004) \\
\end{array}$ & $\begin{array}{r}0.046^{* * * *} \\
(0.004) \\
\end{array}$ \\
\hline loggdp & $\begin{array}{r}-0.164 * * * \\
(0.054) \\
\end{array}$ & $\begin{array}{r}-0.203 * * * \\
(0.053) \\
\end{array}$ & $\begin{array}{r}-0.203^{* * *} \\
(0.053) \\
\end{array}$ & $\begin{array}{r}-0.218^{* * *} \\
(0.053) \\
\end{array}$ & $\begin{array}{r}-0.201 * * * \\
(0.053) \\
\end{array}$ \\
\hline growth & $\begin{array}{r}0.121 * * \\
(0.047) \\
\end{array}$ & $\begin{array}{r}0.122 * * * \\
(0.047) \\
\end{array}$ & $\begin{array}{r}0.122 * * * \\
(0.047)\end{array}$ & $\begin{array}{r}0.124 * * * \\
(0.047)\end{array}$ & $\begin{array}{r}0.122 * * * \\
(0.047) \\
\end{array}$ \\
\hline credit & $\begin{array}{r}0.006 \\
(0.004) \\
\end{array}$ & $\begin{array}{r}0.006 \\
(0.004) \\
\end{array}$ & $\begin{array}{r}0.006 \\
(0.004) \\
\end{array}$ & $\begin{array}{r}0.006 \\
(0.005) \\
\end{array}$ & $\begin{array}{r}0.006 \\
(0.005) \\
\end{array}$ \\
\hline Constant & $\begin{array}{r}3.263^{* * *} \\
(1.472) \\
\end{array}$ & $\begin{array}{r}5.003 * * * \\
(1.657) \\
\end{array}$ & $\begin{array}{r}4.933 * * * \\
(1.644) \\
\end{array}$ & $\begin{array}{r}6.094 * * * \\
(1.772) \\
\end{array}$ & $\begin{array}{r}4.910^{* * * *} \\
(1.586) \\
\end{array}$ \\
\hline$N$ & 5,655 & 5,655 & 5,655 & 5,655 & 5,655 \\
\hline$R^{\wedge} 2$ & 0.248 & 0.248 & 0.248 & 0.249 & 0.248 \\
\hline
\end{tabular}

\begin{tabular}{|l||r|r|r|r|r|}
\hline $\begin{array}{l}\text { FR Measure } \\
\text { Variables }\end{array}$ & \multicolumn{1}{l|}{ lbig8wavg } & lwbig10avg & \multicolumn{1}{l|}{$\begin{array}{c}\text { lavgd55 } \\
(7)\end{array}$} & \multicolumn{1}{c|}{$\begin{array}{c}\text { lavgdv55 } \\
(8)\end{array}$} & \multicolumn{1}{c|}{$\begin{array}{c}\text { wsldistmbc } \\
(9)\end{array}$} \\
\hline \hline$F R$ & $-0.842^{* * *}$ & $-0.577^{* * *}$ & $-0.408^{* *}$ & $-0.397^{* *}$ & $-0.261^{* *}$ \\
& $(0.238)$ & $(0.222)$ & $(0.174)$ & $(0.173)$ & $(0.117)$ \\
\hline polity2 & $-0.020^{*}$ & $-0.019^{*}$ & $-0.020^{*}$ & $-0.019^{*}$ & $-0.020^{*}$ \\
& $(0.011)$ & $(0.011)$ & $(0.011)$ & $(0.011)$ & $(0.011)$ \\
\hline trade & $0.046^{* * *}$ & $0.046^{* * *}$ & $0.046^{* * *}$ & $0.046^{* * *}$ & $0.046^{* * *}$ \\
& $(0.004)$ & $(0.004)$ & $(0.004)$ & $(0.004)$ & $(0.004)$ \\
\hline loggdp & $-0.201^{* * *}$ & $-0.193^{* * *}$ & $-0.193^{* * *}$ & $-0.191^{* * *}$ & $-0.166^{* * *}$ \\
& $(0.054)$ & $(0.054)$ & $(0.054)$ & $(0.054)$ & $(0.054)$ \\
\hline growth & $0.124^{* * *}$ & $0.122^{* * *}$ & $0.122^{* * *}$ & $0.122^{* *}$ & $0.126^{* * *}$ \\
& $(0.047)$ & $(0.047)$ & $(0.047)$ & $(0.047)$ & $(0.048)$ \\
\hline credit & 0.006 & 0.007 & 0.007 & 0.007 & 0.007 \\
& $(0.004)$ & $(0.004)$ & $(0.004)$ & $(0.004)$ & $(0.004)$ \\
\hline Constant & $7.862^{* * *}$ & $6.137^{* * *}$ & $5.997^{* * *}$ & $5.857^{* * *}$ & $4.157^{* * *}$ \\
& $(1.863)$ & $(1.858)$ & $(1.905)$ & $(1.893)$ & $(1.269)$ \\
\hline$N$ & 5,655 & 5,655 & 5,655 & 5,655 & 5,598 \\
\hline$R \wedge 2$ & 0.249 & 0.248 & 0.248 & 0.248 & 0.251 \\
\hline
\end{tabular}


Review of Economic Analysis 11 (2019) 219-232

\section{Appendix B : Middle low- and low-income countries}

Panel A: High Income

\begin{tabular}{|c|c|c|c|c|c|c|c|}
\hline Country & $\mathrm{N}$ & $F D I$ & ldistmbc & Country & $\mathrm{N}$ & $F D I$ & ldistmbc \\
\hline $\begin{array}{l}\text { Antigua \& } \\
\text { Barbuda }\end{array}$ & 38 & 10.315 & 7.491 & Albania & 24 & 5.259 & 7.083 \\
\hline Australia & 46 & 2.224 & 8.378 & Algeria & 23 & 0.422 & 7.396 \\
\hline Austria & 46 & 1.822 & 6.496 & Angola & 20 & 7.000 & 8.424 \\
\hline Bahamas, The & 27 & 4.031 & 7.046 & Argentina & 45 & 1.535 & 8.556 \\
\hline Bahrain & 34 & 4.950 & 8.056 & Azerbaijan & 21 & 17.775 & 7.763 \\
\hline Barbados & 35 & 3.065 & 7.648 & Belarus & 24 & 1.960 & 7.073 \\
\hline Belgium & 14 & 12.046 & 5.188 & Belize & 32 & 5.114 & 7.521 \\
\hline Bermuda & 5 & -0.028 & 6.655 & $\begin{array}{l}\text { Bosnia \& } \\
\text { Herzegovina }\end{array}$ & 17 & 4.081 & 6.886 \\
\hline Brunei & 15 & 2.556 & 7.894 & Botswana & 41 & 3.127 & 8.571 \\
\hline Canada & 46 & 2.225 & 7.378 & Brazil & 34 & 2.082 & 8.218 \\
\hline Chile & 41 & 4.497 & 8.495 & Bulgaria & 26 & 6.669 & 7.171 \\
\hline Croatia & 20 & 4.098 & 6.724 & China & 34 & 2.936 & 7.575 \\
\hline Cyprus & 36 & 4.719 & 7.593 & Colombia & 46 & 2.090 & 7.841 \\
\hline Czech Republic & 23 & 4.544 & 6.533 & Costa Rica & 39 & 3.371 & 7.701 \\
\hline Denmark & 46 & 1.539 & 6.238 & Dominica & 35 & 7.026 & 7.554 \\
\hline Estonia & 20 & 8.341 & 7.035 & Dominican Rep. & 46 & 2.541 & 7.325 \\
\hline Finland & 46 & 1.844 & 7.148 & Ecuador & 40 & 1.138 & 7.993 \\
\hline France & 46 & 1.293 & 5.967 & $\begin{array}{l}\text { Equatorial } \\
\text { Guinea }\end{array}$ & 19 & 16.412 & 8.15 \\
\hline Greece & 28 & 0.807 & 7.218 & Fiji & 37 & 4.587 & 8.381 \\
\hline Hong Kong & 18 & 26.509 & 7.493 & Gabon & 38 & 1.391 & 8.213 \\
\hline Hungary & 24 & 8.504 & 6.856 & Georgia & 19 & 8.146 & 7.661 \\
\hline Iceland & 39 & 1.919 & 7.029 & Grenada & 34 & 8.387 & 7.657 \\
\hline Ireland & 42 & 9.234 & 5.867 & Guyana & 39 & 6.242 & 7.878 \\
\hline Israel & 46 & 1.772 & 7.71 & Iran & 22 & 0.667 & 7.993 \\
\hline Italy & 46 & 0.533 & 6.741 & Iraq & 21 & -0.023 & 7.837 \\
\hline Korea & 40 & 0.639 & 6.535 & Jamaica & 22 & 1.019 & 7.359 \\
\hline Kuwait & 21 & 0.434 & 7.929 & Jordan & 40 & 4.073 & 7.743 \\
\hline Latvia & 20 & 4.227 & 6.975 & Kazakhstan & 24 & 7.143 & 7.983 \\
\hline Lithuania & 20 & 3.311 & 6.929 & Lebanon & 16 & 9.750 & 7.676 \\
\hline Luxembourg & 10 & 23.524 & 5.689 & Libya & 11 & 2.226 & 7.619 \\
\hline Macao & 31 & 4.511 & 7.513 & Macedonia & 22 & 3.742 & 7.114 \\
\hline Malta & 33 & 3.998 & 7.169 & Malaysia & 46 & 3.785 & 7.965 \\
\hline Netherlands & 46 & 10.143 & 5.536 & Maldives & 14 & 7.966 & 8.473 \\
\hline New Zealand & 37 & 2.294 & 8.651 & Mauritius & 39 & 1.413 & 8.707 \\
\hline Norway & 46 & 1.606 & 6.703 & Mexico & 46 & 1.775 & 7.618 \\
\hline Oman & 26 & 1.541 & 8.211 & Namibia & 30 & 4.178 & 8.552 \\
\hline
\end{tabular}


MACHOKOTO, KASIM Financial Remoteness and FDI

\section{Appendix B : Middle low- and low-income countries (continued)}

Panel A: High Income

Panel B: Upper Middle Income

\begin{tabular}{|c|c|c|c|c|c|c|c|}
\hline Country & $\mathrm{N}$ & FDI & ldistmbc & Country & $\mathrm{N}$ & FDI & ldistmbc \\
\hline Poland & 25 & 3.057 & 6.748 & Palau & 21 & 7.613 & 7.588 \\
\hline Portugal & 46 & 2.095 & 6.816 & Panama & 38 & 4.606 & 7.707 \\
\hline Qatar & 15 & 3.028 & 8.073 & Paraguay & 25 & 1.348 & 8.416 \\
\hline Saudi Arabia & 46 & 1.164 & 7.999 & Peru & 46 & 2.201 & 8.163 \\
\hline Seychelles & 39 & 9.724 & 8.529 & Russia & 24 & 1.808 & 7.795 \\
\hline Singapore & 46 & 12.224 & 8.103 & South Africa & 46 & 0.827 & 8.656 \\
\hline Slovak Republic & 23 & 3.495 & 6.783 & St. Lucia & 35 & 9.896 & 7.607 \\
\hline Slovenia & 20 & 1.852 & 6.658 & $\begin{array}{l}\text { Vincent \& } \\
\text { Grenadines }\end{array}$ & 38 & 9.758 & 7.627 \\
\hline Spain & 46 & 1.983 & 6.705 & Suriname & 40 & -4.748 & 7.928 \\
\hline $\begin{array}{l}\text { St. Kitts and } \\
\text { Nevis }\end{array}$ & 36 & 12.348 & 7.468 & Thailand & 41 & 2.094 & 7.95 \\
\hline Sweden & 46 & 2.588 & 6.82 & Turkey & 42 & 0.824 & 7.54 \\
\hline Switzerland & 33 & 3.236 & 6.164 & Turkmenistan & 20 & 7.078 & 7.975 \\
\hline $\begin{array}{l}\text { Trinidad and } \\
\text { Tobago }\end{array}$ & 46 & 5.785 & 7.698 & Venezuela & 44 & 1.022 & 7.748 \\
\hline UAE & 15 & 3.091 & 8.131 & Total & 1,546 & 3.811 & 7.871 \\
\hline Uruguay & 46 & 1.908 & 8.56 & & & & \\
\hline Total & 1,685 & 4.343 & 7.209 & & & & \\
\hline
\end{tabular}

\section{Appendix C : Middle low- and low-income countries}

Panel C: Middle Low Income

Panel D: Low Income

\begin{tabular}{lccc|lccc}
\hline Country & $\mathrm{N}$ & FDI & ldistmbc & Country & $\mathrm{N}$ & FDI & ldistmbc \\
\hline Armenia & 24 & 4.681 & 7.726 & Afghanistan & 13 & 1.440 & 8.14 \\
Bangladesh & 44 & 0.373 & 8.024 & Benin & 46 & 1.083 & 7.973 \\
Bhutan & 14 & 1.728 & 7.98 & Burkina Faso & 46 & 0.552 & 7.886 \\
Bolivia & 46 & 2.764 & 8.301 & Burundi & 17 & 0.150 & 8.339 \\
Cabo Verde & 28 & 4.523 & 7.931 & CAR & 39 & 0.971 & 8.1 \\
Cambodia & 22 & 6.210 & 7.889 & Chad & 39 & 4.185 & 7.912 \\
Cameroon & 39 & 1.158 & 8.075 & Comoros & 28 & 0.873 & 8.542 \\
Congo & 38 & 7.524 & 8.223 & Eritrea & 16 & 4.530 & 8.104 \\
Cote d'Ivoire & 41 & 1.235 & 8.011 & Ethiopia & 5 & 2.392 & 8.214 \\
Djibouti & 17 & 3.224 & 8.204 & Gambia & 20 & 1.255 & 7.931 \\
Egypt & 39 & 2.446 & 7.74 & Guinea & 29 & 2.599 & 7.955 \\
El Salvador & 40 & 1.313 & 7.633 & Guinea-Bissau & 32 & 1.306 & 7.956
\end{tabular}


Review of Economic Analysis 11 (2019) 219-232

\section{Appendix C : Middle low- and low-income countries (continued)}

Panel C: Middle Low Income

\begin{tabular}{|c|c|c|c|c|c|c|c|}
\hline Country & $\mathrm{N}$ & FDI & ldistmbc & Country & $\mathrm{N}$ & $F D I$ & ldistmbc \\
\hline Ghana & 41 & 2.628 & 8.008 & Haiti & 19 & 1.024 & 7.318 \\
\hline Guatemala & 39 & 1.030 & 7.600 & Liberia & 19 & 34.410 & 8.056 \\
\hline Honduras & 42 & 2.856 & 7.566 & Madagascar & 46 & 2.174 & 8.646 \\
\hline India & 41 & 0.733 & 8.273 & Malawi & 46 & 1.984 & 8.502 \\
\hline Indonesia & 35 & 0.975 & 8.035 & Mali & 45 & 1.221 & 7.779 \\
\hline Kenya & 46 & 0.634 & 8.324 & Mozambique & 35 & 7.052 & 8.567 \\
\hline Kiribati & 31 & 0.600 & 8.064 & Nepal & 20 & 0.216 & 8.093 \\
\hline Kyrgyz Republic & 23 & 5.097 & 8.145 & Niger & 46 & 2.448 & 7.820 \\
\hline Lao & 28 & 3.392 & 7.802 & Rwanda & 46 & 0.941 & 8.316 \\
\hline Lesotho & 5 & 0.490 & 8.674 & Senegal & 46 & 1.229 & 7.902 \\
\hline Mauritania & 45 & 3.894 & 7.727 & Sierra Leone & 46 & 2.499 & 8.019 \\
\hline Moldova & 20 & 5.189 & 7.195 & Tanzania & 26 & 3.130 & 8.406 \\
\hline Mongolia & 25 & 8.467 & 7.566 & Togo & 42 & 2.427 & 8.007 \\
\hline Morocco & 46 & 1.062 & 7.222 & Uganda & 28 & 2.949 & 8.281 \\
\hline Nicaragua & 46 & 2.803 & 7.616 & Zimbabwe & 41 & 0.906 & 8.567 \\
\hline Nigeria & 46 & 2.608 & 7.972 & Total & 881 & 2.667 & 8.128 \\
\hline Pakistan & 46 & 0.749 & 8.239 & & & & \\
\hline Papua New Guinea & 35 & 4.062 & 7.978 & & & & \\
\hline Philippines & 46 & 1.097 & 7.559 & & & & \\
\hline Samoa & 22 & 1.834 & 8.437 & & & & \\
\hline Solomon Islands & 25 & 4.814 & 8.090 & & & & \\
\hline Sri Lanka & 46 & 0.895 & 8.341 & & & & \\
\hline Sudan & 44 & 1.626 & 8.011 & & & & \\
\hline Swaziland & 43 & 3.663 & 8.650 & & & & \\
\hline Syria & 29 & 0.716 & 7.691 & & & & \\
\hline Tajikistan & 24 & 3.325 & 8.135 & & & & \\
\hline Tonga & 32 & 1.881 & 8.486 & & & & \\
\hline Tunisia & 40 & 2.423 & 7.161 & & & & \\
\hline Ukraine & 24 & 2.916 & 7.252 & & & & \\
\hline Uzbekistan & 24 & 1.307 & 8.018 & & & & \\
\hline Vanuatu & 35 & 7.646 & 8.290 & & & & \\
\hline Vietnam & 30 & 5.086 & 7.816 & & & & \\
\hline Yemen & 25 & 1.323 & 8.200 & & & & \\
\hline Zambia & 22 & 5.360 & 8.503 & & & & \\
\hline Total & 1,543 & 2.656 & 7.95 & & & & \\
\hline
\end{tabular}

